\title{
THE ELISHA NARRATIVES AND THE COHERENCE OF 2 KINGS 2-8 ${ }^{1}$
}

\author{
Philip E. Satterthwaite
}

\section{Summary}

2 Kings 2-8, containing most of the narratives of the prophet Elisha, are generally held to be somewhat incoherent. Many of Elisha's miracles, in particular, seem both trivial and ill-related to their context. This article argues that the key to 2 Kings 2-8 is provided by the portrayal of Elisha as a 'second Joshua' in ch. 2. In a logical outworking of this chapter, the subsequent narratives set over against each other Elisha's followers and the Northern Kingdom, raising the hope that Elisha's followers will 'conquer' the land, bringing the North back to YHWH. This hope is ultimately not realised. The miracle accounts find their place in this interpretation.

\section{The Problem: Coherence in 2 Ki. 2-8?}

2 Kings 2-8, the chapters in which the majority of the material relating to the prophet Elisha is found, are usually reckoned to pose considerable literary and historical problems. Though Elisha features in every episode, he is found engaged in a range of different activities in which it is hard to see a unifying theme, on the one hand engaging in the politics of his day (war with Moab, ch. 3; war with Aram, chs. 5-7), on the other performing a number of striking, but in the light of the larger context, irrelevant-seeming miracles (ch. 4; 6:1-7). Given the diverse subject-matter and also the differences in length, style, complexity and mood of all these episodes, it is not surprising that some scholars have argued that a variety of sources

${ }^{1}$ This essay is a substantially revised version of a paper given to the staff seminar of Oak Hill Theological College, Southgate, London, on April 17th 1997. I am grateful to the staff of Oak Hill for the invitation to deliver the paper and for their comments upon it. 
underlie these chapters; ${ }^{2}$ nor that some of the proposals made as to the stages by which chs. 2-8 have reached their present form should be quite intricate. ${ }^{3}$ It has been suggested that many of the events narrated in chs. 2-8 did not take place during the reign of Jehoram, where Kings ${ }^{4}$ seems to locate them. ${ }^{5} \mathrm{My}$ impression is that most readers find these chapters difficult. The difficulty consists not in the fact that the individual narratives fail to make clear points about God's dealings with men and women (on the contrary, they are regularly expounded along these lines), but in the fact that it is hard to see why one narrative follows another. This is felt to be worrying, because of an intuition which is partly literary (we ought to be able to relate the parts to the whole in order to understand both better) and partly theological (if narrative incidents seem to follow each other haphazardly, this might suggest a God who has, so to speak, lost the plot in his dealings with his people). In what follows I shall mount a case for the literary coherence of 2 Kings 2-8. The reader may not find all aspects of this case equally convincing, but I hope that it will at least prove suggestive. 6

${ }^{2}$ This view underlies the commentaries of S. Garofalo, Il Libro dei Re (Turin: Marietti, 1960); J. Gray, I \& II Kings. A Commentary (2nd. ed.; London: SCM, 1970); 465-71; M. Rehm, Das zweite Buch der Könige (Würzburg: Echter, 1982); G.H. Jones, I and 2 Kings (London/Grand Rapids: Marshall, Morgan \& Scott/Eerdmans, 1984); E. Würthwein, Die Bücher der Könige. 1. Kön. 17 - 2. Kön. 25 (Göttingen: Vandenhoeck \& Ruprecht, 1984).

${ }^{3}$ As in H.-C. Schmitt, Elisa. Traditionsgeschichtliche Untersuchungen zur vorklassischen nordisraelitischen Prophetie (Gütersloh: Mohn, 1972). On the form-critical categorisation of the Elisha material, see the survey of previous scholarship in R.D. Moore, God Saves. Lessons from the Elisha Stories (JSOTS 95; Sheffield: JSOT Press, 1990) 11-68.

4Throughout I refer to 1 and 2 Kings as 'Kings', reflecting my belief that the two books form a single account.

5So J.M. Miller, 'The Elisha Cycle and the Accounts of the Omride Wars', JBL 85 (1966) 441-54, who argues that the accounts of the wars with Aram more likely belong in the reign of Jehu or his son Jehoahaz.

${ }^{6}$ The historical questions relating to chs. 2-8, e.g., whether the portrayal of Aram-Israel relations in chs. 5-7 fits the period of the Omride dynasty (see Miller, 'The Elisha Cycle', 443-45), cannot be dealt with here. 


\section{Defining the Problem}

2 Kings 2-8 must, of course, be read in the context of the larger narrative of Kings of which they form a part. Kings, on any reading, is a complex account which weaves together a number of narrative strands, and much in 2 Kings 2-8 flows from events earlier in Kings. The end of 1 Kings, especially 1 Kings 19, is important for understanding 2 Kings 2-8. This emerges when we examine 2 Kings 2-8 against the background of three linked themes introduced at the end of 1 Kings.

\section{Destruction of Ahab's Line/War against Baal}

The first two of these themes may be taken together. They relate to the destruction of Ahab's line and YHWH's war against Baal. King Ahab is particularly associated with the introduction of Baal worship into the Northern Kingdom (1 Ki. 16:31-33), and the destruction of Ahab's line is linked to the eradication of Baal worship. Elijah initiates both processes, waging war against Baal (1 Ki. 17-18) and prophesying the end of Ahab's line (21:21-24): Jehu completes them both, destroying Ahab's line $(9: 21-26 ; 10: 1-11)$ and putting an end to Baal worship (10:12-28). Ahab's death in battle at Ramoth Gilead (1 Ki. 22) and the death of Ahab's elder son Ahaziah (2 Ki. 1) are both partial outworkings of the judgment prophesied by Elijah.

Now, the only explicit references to either of these two themes in 2 Kings $2-8$ are at 3:1-3, where Jehoram is said to have got rid of a 'sacred stone of Baal' erected by his father, but not to have abandoned worship at Jeroboam's shrines, and 3:13, where Elisha tells Jehoram, 'Go to the prophets of your father... and your mother' (that is, to the prophets of Baal; cf. $1 \mathrm{Ki}$. 18). It seems likely, however, that both themes form a crucial part of the background to chs. 2-8, and that many episodes in these chapters must be understood in relation to them. Thus the idea of famine as an attack on the claims of Baal's followers and a judgment on Israel for worshipping Baal, expounded at length in 1 Kings 17-18, seems to be presupposed in passages such as 2 Kings 4:38-44 and 8:1-6, in line with a general tendency in Kings to link both military reverses and famine with YHWH's 
judgment on Israel's unfaithfulness. ${ }^{7}$ Similarly, the question of when judgment will fall on Ahab's line hangs over the entire account of Jehoram's reign (3:1-9:26), and particularly surfaces in connection with a theme which is prominent and explicit in chs. 2-8, that of the Aramean threat. To this we now turn.

\section{The Aramean Threat}

War between Aram and Israel dominates 2 Kings 5-8. The theme is first referred to at the time of Baasha (1 Ki. 15:18-21), but the relevant passage for our purposes is 1 Kings 19:15-17, in which the Aramean Hazael is introduced as one of three human agents (the others being Jehu and Elisha himself) who will finally defeat Baal and bring an end to Ahab's line (the second point is implied in the command to anoint Jehu as king over Israel, v. 16). From then on, references to war with Aram are read in the light of this prediction that an Aramean king will be among those used to accomplish these purposes. As the Arameans, at first laughably over-confident and inept (1 Ki. 20), come to pose an ever more formidable threat to Israel in the chapters following, the reader senses a judgment drawing closer to the house of Ahab. It fits with this that Ahab is killed by an Aramean weapon (1 Ki. 22:34-35), and that Jehoram's wounding in battle against Hazael (2 Ki. 8:28-29) is the prelude to Jehu's coup (2 Ki. 9).

1 Kings 19 is important not only for linking the theme of the Aramean threat with those of the destruction of Ahab's line and the eradication of Baal worship, but for the larger point made by the entire account of Elijah's meeting with YHWH on Mt. Horeb. Elijah, who has expected a swift, decisive victory against Baal, is told that events will not follow such a course. A partial answer to the question why it is hard to discern a pattern in the events of 2 Kings 2-8 is surely to be found in this chapter, which represents YHWH's coming judgement on Ahab's line and Baal's followers as like a 'gentle whisper' rather than earthquake or fire (vv. 11-12), suggesting that it will proceed in ways that will at times be almost undetectable. Similarly, YHWH's command to anoint Hazael, Jehu and Elisha

7See especially 1 Ki. 8:33-40; 2 Ki. 17:7-23; and cf. Dt. 28. 
implies both that judgment will be protracted (Elijah's work will have to be carried on by successors) and that it will proceed on a number of fronts (three people are to be anointed). Might we not have expected a long and complex sequel?8

\section{The Miracle Accounts}

If consideration of the above three themes provides a framework for understanding chs. 2-8, how may those parts of chs. 2-8 which we have not so far referred to be fitted into that framework? The narrative in which Elisha takes up Elijah's mantle, and with it Elijah's task (2:1-18), is intelligible in the light of 1 Kings 19: we knew that Elijah's work was to be carried on beyond his lifetime. The narrative of the war against Moab (ch. 3) can be understood along the same lines as the 'Aramean threat' material, as an instance of the recurring pattern in Kings according to which military reverse implies divine judgment. There remain the accounts of Elisha's miracles: the healing of the waters of Jericho (vv. 19-22); the episode of the boys of Bethel and the bears (vv. 23-25); the four accounts in ch. 4; Naaman's healing (ch. 5); the floating axehead (6:1-7). Also to be included here is the episode in which the Shunamite woman of ch. 4 reappears (8:1-6). It is the miracle accounts which seem to raise the greatest obstacles to attempts to read chs. 2-8 as a coherent narrative. They pose two linked problems. Firstly, they seem so trivial: what is their point? Why was it felt important to record them? What is the significance of Elisha's ability to make an unpleasant vegetable stew palatable, or his raising of an axe-head from the Jordan? Secondly, what is their relevance to their context? Naaman's healing is relevant to the theme of war with Aram (see below).

${ }^{8} \mathrm{Cf}$. the comments on $1 \mathrm{Ki}$. 19:13-18 of I.W. Provan, 1 and 2 Kings (Peabody/Carlisle: Hendrickson/Paternoster, 1995) 147: '...the overall strategy was always more long term and more subtly conceived than Elijah imagined. From the beginning it had involved the gentle but devastating whisper as well as the all-consuming fire, the quiet ways of God's normal providence as well as the noisier ways of miraculous intervention.' 
But if we moved some of the other episodes to another position, would it really matter? 9

One answer to these questions essentially accepts that most of the accounts are trivial and loosely related to their context: they arose in prophetic circles which desired to magnify Elisha's reputation, and seem to have been included in Kings for the same reason; beyond this, no significance is to be seen in the facts that the accounts have been placed where they have. 10

In recent years, however, there has been a tendency, particularly represented in the writings of Alter, Berlin, BarEfrat and Sternberg, to question the assumptions underlying this kind of approach.11 It has been asked: does biblical narrative always make connections between events explicit? Is 'simple' juxtaposition as simple as it seems? On closer examination, it appears that the answer to both questions is often ' $\mathrm{No}^{\prime}$. The artless and disjointed surface appearance of some biblical narratives conceals implicit connections between events which readers are expected to note and make sense of. As they do so, they uncover a wealth of significance and pointed evaluation. This narrative strategy may be summed up in the phrase 'implicit commentary': explicit interpretative and evaluative comments are regularly withheld, the narrator instead suggesting interpretations and evaluations by implicit analogies and

\footnotetext{
${ }^{9}$ In both these respects these miracles differ from those of Elijah: the significance of Elijah's miracles is clear, and they are relevant to their context. Thus, for example, the provision of food for the woman of Zarephath (1 Ki. 17:8-16) is a symbolic demonstration, on Baal's territory (the land of Sidon) of YHWH's superiority to Baal; which is the theme of all of $1 \mathrm{Ki}$. 17-18.

${ }^{10}$ So Gray, I \& II Kings, 466-67, and his comment on p. 30: 'Most of these incidents are quite trivial and indicate an authority of little discrimination.' See also Moore's summary of much post-Gunkel work on the Elisha narratives (God Saves, 32-33).

${ }^{11}$ See R. Alter, The Art of Biblical Narrative (New York: Basic Books, 1981); A. Berlin, Poetics and Interpretation of Biblical Narrative (Sheffield: Almond, 1983); M. Sternberg, The Poetics of Biblical Narrative. Ideological Literature and the Drama of Reading (Bloomington: Indiana UP, 1985); S. Bar-Efrat, Narrative Art in the Bible (JSOTS 70; Sheffield: Almond, 1989). See also the similar comments of Provan, 1 and 2 Kings, 1-6.
} 
contrasts. 12 In approaching the miracle accounts of 2 Kings 2-8, my working assumption has been that their seeming triviality and irrelevance to their context is just that: a surface appearance which demands a closer examination.

Another approach, particularly found among more conservative scholars, treats the miracle accounts as neither trivial nor irrelevant to their context, but sums up their relevance to the unfolding narrative in a straightforward and somewhat generalising way. Most of these accounts, on this view, show Elisha meeting the needs of 'ordinary', faithful Israelites, and form a counterbalance to those accounts which deal with national or international themes. Thus, for example, Provan deals with 2 Kings 6:1-23 (the accounts of the floating axe-head and the capture of the blinded Arameans) under the heading 'Miracles, Trivial and Significant', and comments: 'God saves individual Israelites as well as Israel. God's purposes take in the "trivial" as well as the "significant."'13 That is, part of the purpose of these narratives is to challenge the reader's views of what is trivial or significant: they show us something of God's priorities, and his compassion for the needs of his faithful. ${ }^{14}$ In addition, these miracles, which more than once echo those of Elijah, serve to validate Elisha as a worthy successor to Elijah. ${ }^{15}$

But is that all that can be said? It is true that these accounts are local in scope, and that the Israelite ruling classes are generally absent from them (8:1-6 is an exception). But I think there is a further, and equally significant contrast inten-

12This, incidentally, helps to explain why so many modern 'readings' of OT narratives which follow the approach of Alter et al. (this one included) are cumulatively less readable than the OT narratives themselves: in order to bring out clearly what OT narratives convey indirectly, modern interpreters usually find it necessary to replace the subtly suggestive style of the narratives with overly dramatic and/or moralising modes of exposition, which swiftly induce fatigue in the reader.

131 and 2 Kings, 197; cf. also the comments of T.R. Hobbs, 2 Kings (Waco: Word, 1985) 54-55 on the accounts in ch. 4.

${ }^{14}$ In a variation on this approach the account of Naaman's healing is taken to show that YHWH's priorities even include mercy for non-Israelites: R.D. Nelson, First and Second Kings (Louisville: John Knox, 1987) 177, 183; Hobbs, 2 Kings, 69.

${ }^{15}$ So Provan, 187-89, commenting on the accounts in ch. 4. 
ded here, that between faithful Israel and unfaithful Israel. In many of the miracles Elisha is found interacting with Israelites who are characterised in various ways as loyal to him and to YHWH: the 'sons of the prophets', that group almost entirely associated with Elisha in the Old Testament; 16 the Shunamite woman; and others. ${ }^{17}$ These faithful Israelites are set over against the unfaithful Northern Kingdom, the larger Israel of which they are a part, and which is particularly represented in this section of Kings by king Jehoram. By juxtaposing the miracle accounts with narratives relating to the larger Israel, the narrator invites us to draw conclusions about the impact of Elisha's followers on Israel at large. The following pages will argue this point in detail.

\section{Faithful and Unfaithful Israel in 2 Ki. 2-8}

\section{2 Ki. 2}

Elisha's ministry could hardly begin with a more impressive flourish: having crossed into Transjordan and witnessed Elijah being taken up to heaven, Elisha picks up Elijah's cloak, uses it to part the waters of the Jordan and crosses back over into Israel (2:1-18). The point of this extraordinary event is not simply that it validates Elisha as YHWH's prophet, or even that it puts him on a par with Elijah (cf. v. 8), but that it reminds us of the original crossing of the Jordan, when the Israelites entered Canaan under Joshua's leadership. The preceding narrative has more than once suggested links between Elijah and Moses. Like Moses, Elijah meets $\mathrm{YHWH}$ at Horeb and dies in Transjordan. Here we are invited to draw parallels between Elisha, Elijah's successor, and Joshua, Moses' successor. ${ }^{18}$ Is Elisha, the second Joshua, initiating a second 'conquest' of the

16See the excursus on this topic in Hobbs, 2 Kings, 25-27.

${ }^{17}$ Here there is a significant contrast between Elijah and Elisha: the Elijah miracles most closely parallel to Elisha's (1 Ki. 17:8-16, 17-24; cf. $2 \mathrm{Ki} .4: 1-7$, 8-37) are done for a non-Israelite, the woman of Zarephath.

18So B.O. Long, 2 Kings (Grand Rapids: Eerdmans, 1991) 31; Provan, 1 and 2 Kings, 173. However, I find the Joshua-Elisha parallel more significant for the ensuing chapters than these scholars. 
land, in which the people's hearts are won back to YHWH, and the quasi-Canaanite worship of the North purged, completing the process begun by Elijah on Mt. Carmel (1 Ki. 18)? The natural implication of the Moses-Joshua 'typology' is that Elisha (Joshua) completes the conquest which Elijah (Moses) has not lived to see. Are the 'sons of the prophets', who feature prominently in ch. 2, to form the nucleus of a restored Israel?

In this context the account of the healing of the waters of Jericho (2:19-22) strikes an encouraging note. Jericho was the city which Joshua cursed (Jos. 6:26; a fact of which we have been reminded at the end of 1 Kings 16). In healing the harmful waters of Jericho Elisha lifts this ancient curse. ${ }^{19}$ Is his ministry, then, to be one of life and healing? Will he even outstrip Joshua in the blessing he brings to Israel in the land? The next episode (2:23-25) suggests that such blessing will necessarily have judgment as its shadow side. At Bethel, a seat of the false worship instituted by Jeroboam, ${ }^{20}$ Elisha is rejected and calls down a curse which brings death to the young boys who have taunted him. ${ }^{21}$ It is a fierce punishment: the death or capture of children is one of the most devastating forms which judgment can take in the Bible, cutting off the future hope of a people. ${ }^{22}$

The two episodes after Elisha assumes Elijah's mantle, then, represent in miniature faithful and unfaithful Israel, and their respective fates: faithful Israel enjoys $Y H W H$ 's blessings in a renewed Jericho; unfaithful Israel, linked with Jeroboam's idolatrous worship, rejects YHWH's prophet, and suffers a judgment of death. Parallels are suggested between these two

\footnotetext{
${ }^{19}$ So Provan, 174-75, though again with a focus different from mine.

${ }^{20}$ Cf. 1 Ki. 12:28-13:34.

21Various alternative exegetical suggestions notwithstanding, they probably are 'young boys', and they probably are killed (mauled to death). For נערים קטגים NIV suggests 'youths' and H.C. Brichto (Towards a Grammar of Biblical Poetics. Tales of the Prophets [New York/Oxford: OUP, 1992] 198) 'worthless oafs' or 'mean-spirited rascals'; but the three other occurrences of נער קטן in Kings (1 Ki. 3:7; 11:17; 2 Ki. 5:14) seem to have a young child in mind. Similar considerations argue against Brichto's suggestion (ibid., 197-98) that the bears merely 'scatter' or 'break up' the group of boys: the two other occurrences of בקע Piel in Kings refer to the 'ripping open' of pregnant women (2 Ki. 8:12; 15:16).

${ }^{22}$ Cf. Dt. 28:32, 53-55; Hos. 13:16.
} 
groups and the Israelites and Canaanites at the time of Joshua. Here, however, the issue which distinguishes Israelites and 'Canaanites' is the attitude displayed to the prophet. ${ }^{23}$ The last verse of ch. 2, in which Elisha travels first to Carmel, scene of Elijah's most public victory over Baal, and then to Samaria, the royal capital and seat of opposition to $\mathrm{YHWH}$, suggests his determination to take the battle to the heart of enemy territory. ${ }^{24}$ But what will be the outcome? 25

\section{2. $2 \mathrm{Ki} .3$ and 4}

We next encounter Elisha in the wilderness of Edom, where he has seemingly followed the king Jehoram on his expedition against rebellious Moab. Chapter 3 is a fascinating narrative, full of surprising turns of events. ${ }^{26}$ The revolt of Moab against

${ }^{23}$ T. Collins, The Mantle of Elijah (Sheffield: JSOT Press, 1993) 136-39, similarly sees these two episodes as paradigmatic, but in a different way: they reflect a deuteronomistic (exilic) viewpoint, and the fate of the boys of Bethel prefigures the fate of Jerusalem, who loses her 'children' (inhabitants) to 'wild animals' (enemy invaders). In the larger context of Kings, that is, in a sense, true, but the two narratives have a more immediate significance in the account of Elisha's activity following.

24Provan, 1 and 2 Kings, 175.

${ }^{25}$ In suggesting that the presentation of Elisha as a second Joshua is significant for the chapters following, I do not mean to imply that there are clear parallels between incidents in chs. 2-8 and incidents in the book of Joshua. There are no such parallels in chs. 2-8, though some episodes in these chapters do seem to evoke aspects of the conquest under Joshua in a more general way (see the comments on 6:1-7 and 8:1-6). Rather, the two incidents which immediately follow Elisha's (second) crossing of the Jordan suggest the form his 'conquest' will take: those who accept him as YHWH's prophet (that is implied by the respectful request to him in v. 19) will experience YHWH's blessing, in the form of life and material prosperity in the land (here symbolised by wholesome water, vv. 21-22); those who reject him will suffer death (v. 24). The parallel between Elisha and Joshua in $2 \mathrm{Ki} .2-8$ is thus a striking way of raising the possibility that in Elisha's day the people will, in Deuteronomic terms, 'choose life' (Dt. 30:15-20, esp. v. 19), sweeping away Baal worship in a reversal as complete as the conquest under Joshua. Accordingly, a further reason why there are no real parallels in $2 \mathrm{Ki}$. 3-8 to the conquest narratives in Joshua is that this possibility is ultimately unrealised.

26Well charted by Provan, 1 and 2 Kings, 180-84. Like Provan, I see ch. 3 as unitary but complex, and find unnecessary the approach of, for example, 
Israel is a judgment on the house of Ahab.27 But as the chapter develops, and the combined forces of Israel, Judah and Edom drive Moab back, it seems that Moab will after all be subjugated, and the judgment reversed (3:21-25). In a startling final twist, the Israelites are sent reeling back by an anger which seems partly human and partly YHWH's (3:26-27). ${ }^{28}$ Elisha prophesied victory over Moabite forces, but not this final reverse for Israel. Like Micaiah in 1 Kings 22, he has been used to deceive an Israelite king, and thus bring a judgment on him. But it is not a decisive judgment: though Moab is not subdued, and the possibility of subduing Moab is never again envisaged in Kings, Jehoram, unlike Ahab in 1 Kings 22, survives.

There follows the account of Elisha's provision for the widow of a faithful Israelite (4:1-7). It invites comparison with a similar story from the ministry of Elijah (1 Ki. 17:7-16). There are two significant points of contrast. In 1 Kings 17 Elijah's provision for the woman of Zarephath is described in words which suggest its continuance: 'For the jar of flour was not used up and the jug of oil did not run dry, in keeping with YHWH's word spoken by Elijah' (1 Ki. 17:16). Elisha's provision for the Israelite woman is described so as to suggest that, though abundant, it came to an end: 'Then the oil stopped flowing' (2 $\mathrm{Ki} .4: 6)$. In practice the two narratives may imply the sameeach woman receives enough for her needs-but the different wording may be significant. Secondly, Elisha's provision

Würthwein (1. Kön. 17 - 2. Kön. 2, 281-87), who attempts to resolve the complexities by arguing for a number of textual layers in 3:24-27.

${ }^{27} \mathrm{This}$ is how other revolts against Israel are interpreted in Kings ( $1 \mathrm{Ki}$. 11:14-25). This interpretation is also implied by $1: 1$ and 3:4-5, in which Moab's revolt is portrayed as a consequence of Ahab's death, itself an outworking of divine judgment.

28So Provan, 1 and 2 Kings, 186. The ambiguous reference to 'great anger' (קצך) forces us to ask: whose anger? It is unlikely that Chemosh's anger is intended (Kings never allows that the gods of the nations have any power); and equally unlikely that $\mathrm{YHWH}$ here responds favourably to child-sacrifice, a practice he is elsewhere said to detest ( $2 \mathrm{Ki} .16: 3 ; 17: 17$; 21:6). More likely, the anger is that of the Moabite soldiers responding to their king's sacrifice, but the reverse which they inflict on the Israelite coalition must also be seen as an expression of YHWH's anger against them. 'The Moabites' anger would have counted for nothing, had God not ordained that is should count for something' (Provan, ibid.). 
involves the filling of vessels (vv. 4 and 6), again a point that is not stated in the earlier narrative. I wonder if some analogy is here suggested with the immediately preceding narrative: there, too, YHWH has miraculously filled pools of water, and thus delivered Israel;29 and the latter stages of the war against Moab might be described as a case where YHWH's blessing finally stopped, and stopped, on that occasion leaving his people well short of final deliverance..$^{30}$ There is, of course, a danger in this approach, that of summarising narratives in a way that makes them seem closer than they really are. Nonetheless, is there a parallel? If so, what point is made? That faithful Israelites enjoy greater blessing than the unfaithful king ( $c f$. Elisha's rebuke in 3:13-14)? That they enjoy abundance in the land, whereas the unfaithful suffer defeat at enemy hands? 31 Or that the larger Israel will come to enjoy blessings like those of the widow? For the moment, the question is left hanging.

The following, much longer account of the Shunamite woman and her son (4:8-37) can also be compared to a similar episode from the ministry of Elijah (1 Ki. 17:17-24). But again, there are points of contrast: firstly, Elisha, unlike Elijah, ministers to an Israelite woman; secondly, whereas Elijah revives a son who already existed before he came on the scene, in this narrative there is a preliminary stage, Elisha's promise of a son, and the birth of this son (4:14-16). The giving of this promise transforms the narrative, suddenly raising the stakes and heightening its intensity. The woman's response to what should be happy news is startling: 'No my lord! Man of God, don't deceive your servant!' (4:16). Why this anguished tone? It quickly becomes apparent why: the boy's first words are a shout of pain, after which he dies (vv. 19-20); the woman then travels to confront Elisha with what has come of his promise, brushing aside all who stand in her way (vv. 21-28); there follows a lengthy healing account, in which the boy is only

\footnotetext{
מלא29 ('fill') is used at 3:17, 20 and 4:4, 6.

${ }^{30}$ Contrast the positive ending in $2 \mathrm{Ki} .4: 7:$ " $\mathrm{Go}$, sell the oil and pay your debts. You and your sons can live on what is left."'

${ }^{31}$ Even if one does not accept that the narratives of 3:1-27 and 4:1-7 are linked in a loose analogy, it is still possible to read a constrast of this sort into the fact that they are here juxtaposed.
} 
healed at the third attempt (vv. 29-35). Virtually every note sounded in the narrative, until the very end, is of pain, difficulty, distress, bitterness and uncertainty. Why is this?

The account is a deviant version of a familiar Old Testament 'type-scene' in which a child is promised to a childless woman. It is a type-scene particularly characteristic of Genesis, and particularly linked to that theme which above all dominates Genesis, that of the promised 'seed' who, contrary to expectation, will become a great nation. Indeed, Elisha's promise that 'this time next year you will hold a son in your arms' (v. 16) apparently echoes the angel's words to Sarah at Genesis 18:10. The narrative thus seems to be making some point about the future of Israel, the heirs of the Genesis promises. Elisha, perhaps, has seen in the barren Shunamite's condition the occasion for an act that will be a sign for Israel in his day (vv. 14-16), but is then surprised when the son who is born as a result dies. The words in which he expresses his surprise ('YHWH has hidden it from me and has not told $\mathrm{me}^{\prime}$, v. 27) highlight a question which lies behind all of chs. 2-8: what are YHWH's purposes for Israel?32 The fact that the son is only with difficulty resuscitated (vv. 29-35) may suggest the difficulty with which Israel clings on to life. The notes of pain and death, dwelt on at such length, are ominous. But again the point is unfocused. Is it that the Northern Kingdom is still (barely) viable? That it will (narrowly) survive? Whom does this son represent? Elisha's followers, who will succeed in bringing life to the nation? Or is the death the death of national exile? Who will survive, and how? 33

32Thus (contra Würthwein, 1. Kön. 17 - 2. Kön. 25, 294) the words do not simply make a general point about prophecy (the man of God derives his insight entirely from $\mathrm{YHWH}$ ), and they are not a later addition to the text. 33The 'type-scene' approach to 4:8-37 has already been advocated by $R$. Alter, 'How Convention Helps Us Read: The Case of the Bible's Annunciation Type-Scene', Prooftexts 3 (1983) 115-30, esp. 125-26. In Alter's view, the peculiar handling of the conventions in this episode suggests satirical intent: Elisha is presented as one who misuses his powers, promising the son in return for the hospitality he has received; the 'gift' goes disastrously wrong when the son dies, and Elisha only with difficulty rescues the scene by resuscitating the son. Elisha's in effect arbitrary (self-serving) use of his powers is shown up by the fact that the 
The next two episodes, death in the pot (4:38-41) and the multiplication of the barley-loaves (4:42-44), both describe the provision of food by Elisha for the 'sons of the prophets'. There is a similar pattern to the two episodes: in each a preliminary attempt to provide food for the 'sons of the prophets' runs into difficulties (vv. 39, 42); a protest is made to Elisha (vv. 41b, 43a), who has initiated both attempts (vv. 38a, $42 \mathrm{~b}$ ); Elisha confirms his earlier instructions (vv. 41b, 43b); 34 the 'sons of the prophets' are able to eat. As before, differences between the episodes are also significant.

In the first episode Elisha's instruction to 'boil up some soup' is a response to a general famine in Israel. That is, YHWH's judgment is again making itself felt in the land: the only fruits the land now produces in abundance are (or at least taste) poisonous (vv. 39-40).35 Elisha renders the stew edible, but the suggestion in this episode is of death only narrowly avoided. At the beginning of the second episode the land has begun to yield wholesome produce again (v. 42). In the context of the preceding verses, the reference to first-fruits of barley and fresh produce suggests a lifting of judgment, the more so when Elisha multiplies this produce with the words " For this is what YHWH says: 'They will eat and have some left over'"' (v. 43; cf. v. 44b). This episode deals with the same themes as the previous one, but more positively: the land of Israel is showing signs of renewed life.

Reviewing the four accounts of ch. 4, it may be seen that they trace a positive progression: there is a clear movement from life to death in the second of them (vv. 8-37) and also in the third and fourth taken together (vv. 38-44). In a similar way, if the first account (vv. 1-7) has shown Elisha providing for the

son, unlike those in Genesis, has no significant in the ensuing narrative: 'a professional man of God may through his own initiative turn the old annunciatory trick, but this is a far cry from being an emissary sent by God, who can by virtue of the divine plan he serves announce the birth of a son who will affect the course of history' (ibid., 126). My own reading, I suggest, better relates the details of the episode to the context in 2 Kings.

34These two climactic utterances are closely similar in form: צק לעם ויאכלו ('pour it out for the people so that they may eat', v. 41b); תן לעם ויאכלו ('give it to the people so that they may eat', v. 43b).

${ }^{35}$ See fn. 7 above. Contrast Dt. 8:7-10. 
material needs of one family, the third and fourth accounts describe a similar provision on a much larger scale. ${ }^{36}$ Is there then hope for Israel at large? Are Elisha's followers the 'firstfruits' of a restored Israel?

\section{2 Ki. 5:1-8:6}

The scene now changes with the introduction of Naaman the Aramean (5:1). 2 Kings 5-8 is dominated by the linked themes of Aramean attacks and God's power at work in Israel through Elisha. R.D. Moore's study of chs. 5-7 forms a good startingpoint for our discussion. ${ }^{37} \mathrm{He}$ argues that the three main accounts in chs. 5-7, concerning Naaman (5:1-27), Elisha and the blinded Arameans (6:8-23) and the siege of Samaria (6:24-7:20), are a re-working of exodus and conquest traditions, a 9thcentury response to the Aramean military threat which sets out a distinctive vision of how Israel continues to experience YHWH's salvation. ${ }^{38}$ Salvation, in these accounts, belongs to $\mathrm{YHWH}$, who declares his intentions through his prophet. Aramean military might is powerless against YHWH (6:13-23; 7:6-7). Salvation, however, is revealed in surprising ways, through a captured Israelite slave girl (5:2-3), or through four hungry lepers $(7: 3-5,8-11)$. The powerful are sometimes humbled as a result, like Naaman (5:9-15), or in other ways bypassed, like the king of Israel during the siege of Samaria (6:27; 7:12-15). In a striking departure from earlier traditions, Israel's deliverance never involves the destruction of Arameans, this being explicitly vetoed at 6:21-23 ( $c f$. also 7:6-7). Moore concludes that the accounts in $2 \mathrm{Ki}$. 5-7 are 'didactic salvation stories': they re-affirm YHWH's ability to save; and the manner of this salvation, in which military power, Israel's as well as Aram's, is irrelevant to the outcome, suggests that the accounts may be specifically directed against those in Israel, perhaps connected with the royal court, who were advocating reliance

\footnotetext{
36It may be significant that the same root (יתר) is used in both the first and the fourth narratives to suggest the abundance of this provision (v. 7 [Niphal], vv. 43, 44 [Hiphil]).

${ }^{37}$ God Saves (see fn. 3 above).

${ }^{38} \mathrm{Ibid} ., 128-47$. Moore offers no detailed discussion of the axe-head episode (6:1-7).
} 
on military might rather than on YHWH's intervention. ${ }^{39}$ The accounts could date from either the reign of Jehoram or that of Jehu. ${ }^{40}$

I accept many of the details of this interpretation, and, indeed, some of the larger points, but wish to set them in a different interpretative framework. Firstly, though it is a formal possibility that the Israelite king referred to in chs. 5-7 is Jehu, I think it more likely that the king in question is Jehoram, as implied by the placing of these chapters before the description of Jehoram's death in ch. 9. Chapters 5-7 make best sense when interpreted as describing the closing stages, in fact the final turning point, of Jehoram's reign, and chs. 8-10 form their natural continuation. In particular, ch. 8 is in my view only intelligible as the sequel to chs. 5-7. Secondly, though Moore's discussion of the manner of YHWH's salvation in 2 Kings 5-7 does include some comments on the role of the king vis-a-vis YHWH's saving activity, ${ }^{41}$ he does not focus on the relations between the king and Elisha. I suggest that one of the main functions of chs. 5-7 is to trace a sharp decline in these relations. Thirdly, it is possible on this basis to suggest why the axe-head episode (6:1-7) and the episode of the Shunamite woman (8:1-6) are placed where they are within chs. 5-8.

Chapter 5 begins by introducing Naaman as military victor and stating, briefly but shockingly, that it is $\mathrm{YHWH}$ who has given Aram victory through him.42 A reference to earlier Aramean raiding parties (v. 2) implies that Aramean military

${ }^{39}$ Ibid., 145-47.

40Ibid., 128-29, citing Miller, 'The Elisha Cycle'. The fact that the chs. 5-7 at no point name the king of Israel leaves either possibility open.

${ }^{41} \mathrm{As}$ in his comments on the ineffectiveness of the king's interventions in 6:24-7:20 (God Saves, 103).

נתן-יהוה תשועה לארם42 ('YHWH had given Aram victory'). Perhaps the reference is to the battle of $1 \mathrm{Ki}$. 22. The phrase נתן תשועה ('bestow victory') is elsewhere sparsely attested (Judg. 15:18; Is. 46:13; Ps. 144:10; the usage in Ps. 14:7//53:7 [מי־יתן תשועה] is somewhat different), but in each case victory is something YHWH bestows on Israel. Note also the much larger number of texts in which $\sqrt{ }$ ישעי Hiphil ('save') occurs with as subject and Israelites as the object, usually with military victory in view: for example, Ex. 14:30; Dt. 20:4; Judg. 2:16; 1 Sa. 7:8; 2 Sa. 8:6; and, especially relevant, $2 \mathrm{Ki}$. 6:27 (negatively). That YHWH here gives victory to Aram is thus highly unusual and significant for the narrative. 
success is starting to threaten Israel. Between 5:3 and 6:23, the narrator raises the possibility that $\mathrm{YHWH}$ has reversed his policy vis-à-vis Aram as, in increasingly clear ways, he acts through Elisha so as to counteract Aram's military power and bring about peace for Israel. From 6:24 on, this possibility swiftly recedes, with dire implications for both Jehoram and Israel. The turning point in these chapters thus occurs between 6:23 and $24 . .^{43}$ In what follows I briefly expand this outline, paying particular attention to the role in these chapters of $6: 1-7$ and 8:1-6.

(1) 5:1-27: Verses 1 and 2 locate the Naaman episode in a context of sporadic war between Israel and Aram.44 Kings' theology of Israel's wars (victory = blessing, defeat = judgment) is, as noted, bluntly evoked by the statement in v. 1 that 'YHWH had given Aram victory'. I suggest that it also supplies the key for interpreting the Naaman episode. Naaman is significant, not primarily as an example of YHWH's favour shown to a non-Israelite, ${ }^{45}$ but for what his healing implies for YHWH's involvement in Aram-Israel relations, hence for his attitude towards Israel. ${ }^{46}$ But where do matters stand at the end ch. 5 ? YHWH has clearly been involved in Naaman's healing, ${ }^{47}$

43There is a clear break between these verses. Note the inclusio between $6: 23 \mathrm{~b}$ ('so the bands from Aram stopped raiding Israel's territory') and the similar reference to Aramean raiding parties in 5:2; also the words with which 6:24 begins (ויהי אחרי־כ, 'subsequently'), which mark a mark a new stage, as Ben-Hadad musters his entire army against Israel.

${ }^{44} \mathrm{Ch}$. 5 seems to be set in a period of relative peace (vv. 5-7 make little

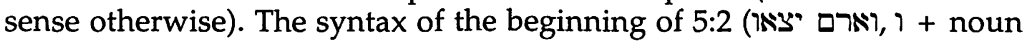
followed by perfect) also implies that the raids lie in the past.

${ }^{45}$ Contra J. Ellul, The Politics of God and the Politics of Man (ET; Grand Rapids: Eerdmans, 1972) 25-28.

${ }^{46} \mathrm{~A}$ point suggested by the chiastic arrangement of the four responses to Naaman's leprosy in vv. 3-8: the first (the servant-girl's, v. 3) and the fourth (Elisha's, v. 8) focusing on the presence of a prophet in Israel; the central two (the responses of the kings of Aram and Israel, vv. 5-6, 7) suggesting the implications of Naaman's healing (or non-healing) for Aram-Israel relations.

47 In refusing to perform any healing rituals (5:9-11) and in refusing to take a gift from Naaman $(5: 15 b-16)$ Elisha deliberately draws attention to the fact that it is YHWH who has healed him. So Provan, 1 and 2 Kings, 193. 
and this healing deprives the king of Aram of a possible excuse for war (5:7). But, as 6:8ff shows, he does not in any case need one. At most, Naaman's healing may make for peace and, as it turns out, does not do so immediately. It is an unclear indicator of YHWH's intentions towards Israel. Further, there is an irony in the climax of the account, where a non-Israelite proclaims the supremacy of the God of Israel with greater conviction and humility than Jehoram, king of Israel, has shown so far.

(2) 6:1-7: Why does the narrative of the floating axe-head occur at this point? It is important, firstly, to see the significance of the restoration of the axe-head in the context of 6:1-7. The starting-point of this episode is that the 'sons of the prophets' are increasing in number. This is encouraging: perhaps the faithful Israel is beginning to assume significant proportions. The action the 'sons of the prophets' propose, building a place to dwell near the Jordan, evokes memories of the conquest under Joshua. 48 It seems to be a deliberate gesture: now that Elisha's followers are growing in numbers, they may start to 'take possession' of the land, starting from the Jordan. Thus the restoration of the axe-head implies not simply YHWH's concern about the possible embarrassment of one of his faithful, but an endorsement of the symbolic repossession. Other details may also have symbolic significance: the fact that the axe-head was borrowed (v. 5) may suggest that the power sustaining the sons of the prophets is not inherent to them, but derives from YHWH; the fact that only Elisha has the skill and discernment to restore the axe-head suggests the crucial role of Elisha, YHWH's prophet, among the sons of the prophets; 49 v. 7 suggests the importance of doing what the prophet says. 50

${ }^{48}$ Compare the comments on ch. 2.

${ }^{49}$ Elisha's role is also highlighted by the (at first sight unnecessary) dialogue of vv. 2-4, in which Elisha initially merely gives the prophets permission to go, and sets out with them only when asked: the 'sons of the prophets' need Elisha with them if they are to succeed.

${ }^{50} \mathrm{My}$ reading of 6:1-7 may be compared to that of H.C. Brichto, Towards a Grammar of Biblical Poetics, 198-200. He argues that the narrative is a symbolic depiction of the nature of prophetic power: the trainee prophet does not wield the prophetic gift (the axe-head) rightly, and is prone to lose it; he must be instructed and shaped by the master-prophet before the 
However, this episode also seems to resonate with the Naaman episode, as may be seen if we express the outline of the Naaman episode in terms drawn from 6:5-7: the king of Aram has lost his axe-head (Naaman, his victorious general, incapacitated through leprosy), which is restored to him after immersion in the Jordan when Naaman does what Elisha says. 51 However, if the broad outline of the episodes is similar, there is also a significant difference: the Naaman episode was ambiguous as regards YHWH's commitment to Israel's welfare; but here his power directly aids the (Israelite) 'sons of the prophets'. The next episode will take this development further.

(3) 6:8-23: As noted, peace does not immediately arrive after Naaman's healing. The king of Aram engages in raids on Israel, which are repeatedly foiled by the intervention of Elisha (6:810). The episode culminates in the revelation of the fiery horses and chariots of $\mathrm{YHWH}$ at Dothan (6:17), and the parallel 'revelation' when the eyes of the Aramean soldiers are opened in Samaria (6:20). Again, there are broad similarities between this episode and 6:1-7: a lost axe-head is restored to the king of Aram (the large raiding party he sent to capture Elisha);52 6:2122 stress the importance of obeying Elisha's word. But again the differences are significant. In every sense this episode represents the climax of the progression which has begun at 5:1: for the first time YHWH's power has clearly been engaged for Israel and against Aram, and this time it is Israel as a whole,

gift can become a permanent endowment. Whereas Brichto takes the narrative as making a general point about prophecy, in my view the narrative is directly focused on the relationship between Elisha and his followers, and is more closely related to its context than Brichto's view would imply.

${ }^{51} \mathrm{As}$ in the earlier discussion of the relationships between 3:1-27 and 4:1-7, if one does not accept that there is a narrative analogy between 5:1-27, 6:17 and 6:8-23 (and it must be admitted that narrative analogies in the Old Testament are usually more clear-cut than those suggested here), it still remains possible to treat the positioning of 6:1-7 as significant, in that it suggests parallels between the fortunes of the 'faithful Israel' and those of the larger Israel.

${ }^{52}$ Alternatively, or as well, YHWH's power (the fiery chariots and horses) corresponds to the axe-head, and it is Israel to whom it is restored. 
and king Jehoram in particular, not simply Elisha's followers, who benefit (symbolised by Elisha's leading the Arameans captive to Samaria, the royal capital). The double revelation of YHWH's power, which has lain under the surface in the previous two episodes, is similarly climactic $(6: 17,20) .{ }^{53}$ Aram has been reduced to military impotence and, as a result, 'Aramean bands no longer entered Israelite territory' (v. 23b).

In 2 Kings 2:1-6:23 we have noted how the narrator has set over against each other Israel, represented particularly by king Jehoram, and a smaller group of those faithful to Elisha. The programmatic ch. 2 has raised the question: how will the faithful Israel impinge on Israel as a whole? The narratives in chs. 3-6 have suggested that there may be a positive outcome, in that the fortunes of both groups have improved. The larger Israel may have suffered a reverse by the walls of Moab (ch. 3), but chs. 5-6 have seen Aram's attacks on them first blunted and finally halted. Elisha's followers also seem to have flourished, as indicated by the progression of the narratives in ch. 4 , and by $6: 1-7$, in which growth in numbers leads to the establishing of a symbolic bridgehead by the Jordan. The fortunes of both groups, in fact, seem to be running increasingly in parallel: if the earlier episodes $(4: 1-7 ; 4: 8-37)$ are ambiguous about the relationship between Elisha's followers and the larger Israel, then the two episodes in 4:38-44 and the loose narrative analogy of the three episodes in 5:1-6:23 hint at a convergence of fortunes which will have a positive outcome for Israel as a whole.

In particular, relations between Elisha and the king seem relatively good in 6:8-23 (contrast 3:13-14). Elisha takes the initiative in warning Jehoram of Aramean raiding bands (vv. 9-10), and Jehoram obeys Elisha in sending the captured Arameans home (vv. 21-23a). Perhaps such obedience is to be a permanent characteristic, and he will escape the judgment hanging over his father's house (Ahab, it will be recalled, secured a similar remission, $1 \mathrm{Ki}$. 21:27-29). However, it is significant that at the end of this last episode Elisha criticises the king for proposing a course of action, killing the captured

${ }^{53}$ Moore speaks of 'a new vision of YHWH's power' which 'replaces the blindness of Israelites and Arameans alike' (God Saves, 94). 
Arameans, that, as well as jeopardising peace, would draw attention away from the fact that the capture is entirely YHWH's work.54 Throughout 5:1-6:23 YHWH has delivered Israel using uncon-ventional means: healing an enemy commander; capturing alive and sending home a powerful enemy force (Naaman's healing writ large, in effect); and never in the way familiar from Israel's past, by giving them victory over enemies in a battle in which Israel's forces are deployed. Never in these episodes does an Israelite take up a weapon: the peace Israel now enjoys has been the unaided work of YHWH, revealed through his prophet. That is, $\mathrm{YHWH}$ has made it clear that Israel's survival depends on him. In a way Moore's view of chs. 5-7 overall, that they are directed against 'monarchical trends... to dismiss the validity of Yahwistic warfare', 55 is a true reading of $6: 8-23$. But the point should be focused more narrowly on the immediate context: YHWH has shown this king, Jehoram, at a particular stage of his reign, in whose hands Israel's salvation really rests. Will he accept this? What if YHWH's power ceases to be available for the larger Israel? What if relations between Jehoram and Elisha, who has played such a crucial role up to this point, deteriorate? These are questions addressed in what follows.

(4) 6:24-7:20: This episode begins with a terrible inversion of the preceding scene. The Arameans are back in force and this time, far from being effortlessly disarmed, stay to besiege Samaria ( $v$. $24 ; c f$. v. 20). Famine grips the city that was once able to hold a feast for its captives (v. 25; cf. v. 23). YHWH has apparently drawn near in judgment, but no reason is given for this: the opening words ('some time later', ויהי אחרי־כ) offer no hint as to what has changed in the interim. There follows an exchange (6:26-27) in some ways similar to that at 5:6-7: an 'impossible'

546:21-22. Gehazi's action in 5:20-24 has similarly tended to detract from YHWH's power. In these two incidents, which come at similar points in the structure of the accounts in which they stand, the narrator hints at a kind of spiritual kinship between Jehoram and Gehazi. This idea is picked up in 8:1-6.

55 God Saves, 145. 
request, which meets with a conventionally pious response. 56 But this time there is a pregnant silence, 57 which draws the king into. asking a question. There follows a horrific tale of cannibalism, all the more horrific for being told in short, unadorned phrases, as though, given the situation, nothing could be more natural than the events the woman describes. 58

Something snaps in Jehoram. The narrator has noted that Jehoram was on the wall (6:26); now this detail is picked up as he makes a startling public gesture (6:30). The act of tearing robes, which merely reinforced a conventional response at 5:7, is here singled out and given a startling new meaning as the king reveals sackcloth that might suggest penitence, 59 but follows this with words of rage against Elisha and YHWH: 'May God deal with me never so severely, if the head of Elisha... remains on his shoulders today!' (v. 31). And again, as he goes in search of Elisha to kill him: 'The disaster is from YHWH. Why should I wait for YHWH any longer?'60

It is a stunning revelation. In the introduction to Jehoram's reign (3:1-3) the narrator has suggested that his piety is compromised. Here, under pressure of severe judgment from YHWH, Jehoram responds with hostility and impenitence. It is not a wise, or even a logical response (if Jehoram really believes the disaster is from $\mathrm{YHWH}$, how can he believe killing Elisha will avert YHWH's judgment? and then why confirm this intention by invoking $\mathrm{YHWH}$ ?); but it seems to reveal what is

\footnotetext{
56Either: 'If YHWH will not save you, how can I save you?' (so GK 109H; Driver, Tenses, §152(3). Or: 'No! Let YHWH save you. How can I save you?' In either case it is plain that YHWH is not saving at present.

57Indicated by the introductory formula (ויאמר־לה המלך, 'and the king said to her') at the beginning of v. 28, which would not otherwise be necessary, since the king is the speaker in v. 27.

58The passage evokes memories of two passages: Dt. 28:53-57, in which cannibalism during a siege is an extremity to which unfaithful Israel may be reduced; and $1 \mathrm{Ki}$. 3:16-27, the account of Solomon's judgment between the two prostitutes. As Nelson notes (First and Second Kings, 189), 2 Ki. 6:26-31 forms 'a grim analogical contrast' to the 1 Kings passage.

${ }^{59}$ Compare $1 \mathrm{Ki} .20: 32$ and, particularly, $1 \mathrm{Ki} .21: 27-29$.

${ }^{60}$ The words are placed in the mouth of Jehoram's messenger, but they surely express Jehoram's own attitude. So Provan, 1 and 2 Kings, 203.
} 
really in his heart.61 A glaring contrast with Naaman's attitude to YHWH (5:15-19) suddenly becomes apparent. Here, too, seemingly, is the explanation why YHWH has drawn near in judgment in the first place: a king who is at best half-hearted in his commitment to $\mathrm{YHWH}$ and who in the end turns away from him. 62

The irony is that salvation is about to be revealed. As Jehoram and his servants come to kill Elisha, Elisha meets them with a word of YHWH promising a complete reversal of the present situation (7:1). YHWH's horses and chariots have been absent, but now they return to drive the Arameans away (7:6; cf. 6:17), and Samaria is delivered. Ominously, however, given that the real power of life and death has remained in YHWH's hands throughout, Jehoram is now thoroughly estranged from $\mathrm{YHWH}$ and Elisha. The king indicates his attitude to $\mathrm{YHWH}$ by his mistrustful response to the lepers' report (7:12), and never again speaks to Elisha in the subsequent narrative. Elisha's description of him in 6:32 as 'this murderer' suggests that the estrangement is mutual. The lengthy description of the death of the king's officer for his mockery of Elisha's prophecy (vv. 1-2, 17-20) suggests that a similar fate awaits the king himself.

(5) 8:1-6: This is the context for the last of the 'faithful Israel' episodes, the restoration of the Shunamite woman's property (8:1-6). It has four unusual features: firstly, Elisha himself is absent. Secondly, it is the only such episode in which a representative of the larger Israel, Jehoram himself, plays an active part (Gehazi seems to have joined his court). Thirdly, it refers to earlier narratives: there is a reference to the previous narrative in which the Shunamite featured $(8: 1,5 ; c f .4: 8-37)$, and, in a further allusion to what has preceded, Jehoram asks

61Jones (1 and 2 Kings, 430) argues that 6:30 and 31 must come from different sources, so different are the religious attitudes expressed. The difference, indeed, could not be more complete. We should attribute this, however, not to discrepant sources, but to the discrepancy between Jehoram's external gestures and his true attitude to YHWH.

${ }^{62}$ This narrative, therefore, is a good example of the technique of withholding material facts until they can have maximum impact; $c f$. Sternberg, Poetics, 309-20, and also the comments on 8:1-6 below. 
Gehazi to tell him about Elisha's great deeds (v. 4). Fourthly, it begins with a 'flash-back' to events seven years in the past (vv. 1-2), of which the reader has not previously been informed. 63

It has been suggested that this episode is out of sequence: for example, that it originally stood after $4: 8-37,64$ or that the episode presupposes Elisha's death (hence the king has to ask Gehazi for an account of Elisha's deeds) 65 Neither suggestion seems necessary. If we treat 8:1-2 as a 'flash-back', that implies a gap of at least seven years (see 8:1-3) between 4:37 and 8:3, time enough for the events in the intervening chapters to have taken place. This fits with the reference to 'all the great things Elisha did' (v. 4), which suggests that 8:1-6 stands towards the end of Elisha's ministry. On the other hand, there is no warrant for supposing that Elisha is dead; more likely, after the events of ch. 7 he no longer associates with Jehoram. I suggest that the location of this episode, just before the narratives in which Elisha sets Hazael and Jehu in motion against Israel and Jehoram (8:7-15; 9:1-10), must be taken seriously: the purpose of the episode is to convey how things stand with Jehoram and with Israel on the eve of impending disaster. It does this is by bringing together and contrasting representatives of the nation Israel and 'faithful Israel'.

We noted above that the account of the birth of the Shunamite's son was reminiscent of similar accounts in Genesis, and thus raised the question of Israel's future: perhaps, like the son, Israel would survive through the ministry of YHWH's prophet. But as it turns out, the woman and her son are not at all representative of Israel's fortunes. Three times she is referred to as 'the woman whose son [Elisha] had brought to life' (8:1, 5 [twice]), and nowhere is it suggested that

63The opening of 8:1 would fit with the 'flashback' view, as the syntax ( ו ואלישט דבר + noun) is that which would be used to denote events anterior to the main narrative (in this case, 8:3-6); $c f$. the comments on 5:2 (fn. 44 above). When, on this view, might the events of 8:1-2 have taken place? Most likely the famine in question is that referred to at 4:38; and so 'the warning cited here was given to the woman around the same time that Elisha restored her son to life' (Provan, 1 and 2 Kings, 207).

${ }^{64}$ So Garofalo, Il libro dei Re, 191, 207.

65So Gray, I \& II Kings, 525; Rehm, Das zweite Buch der Könige, 82. 
this restoration to life has any relevance for Israel.66 On the contrary, we now learn that for seven years Israel has been in the grip of a famine, with its clear connotations of judgment and death. During this time the woman and her household have been dwelling among the Philistines, a clear symbol of the gap that has divided their fortunes from those of the nation Israel (v. 3). ${ }^{67}$ The delayed revelation of these facts causes us to see the events in the intervening chapters in a very different light: the multiplication of the barley-loaves and grain (4:42-44) did not, after all, indicate the lifting of famine; 68 the hope raised in 6:21-23 that Jehoram might learn obedience to Elisha, and Israel experience permanent peace under his rule was illusory; and the possibility hinted at in 5:1-6:23 that the paths of the faithful Israel and the nation Israel might eventually merge, and the nation Israel return to $\mathrm{YHWH}$, is decisively rejected in 8:1-6, which marks the sharpest possible divergence between the paths of the Shunamite and the nation Israel.

The same point emerges if we compare 8:1-6 and the beginning of Elisha's ministry in ch. 2 . If that chapter raised the possibility that he might bring into being a renewed Israel that would conquer the land in YHWH's name, then 8:1-6 describes what is, in Old Testament terms, the appropriate end to a conquest, Israelites taking possession of their inheritance (v. 6): but the Israelites in question amount to just one household. The 'conquest' has had no real impact on the Northern Kingdom.

Jehoram, too, is contrasted with the woman in a way which well fits his position at the end of ch. 7. In this episode the woman is consistently linked with life and the preservation of life. Jehoram hears of the miracle which brought her son

66This, of course, implies (contra Alter, 'How Convention Helps Us Read', 125-26) that the Shunamite's son has been significant in the narrative after ch. 4: his significance consists in his ultimate irrelevance to Israel's fate.

${ }^{67}$ This verse may echo other Genesis accounts, those in which patriarchs flee the land during famine (Gn. 12:10-20; 26:1-11). If the echoes are intended, they would reinforce the gap between the Shunamite's family and the larger Israel, as they would equate the larger Israel with the Canaanite inhabitants of the land at the time of the patriarchs.

68Though, as Rehm notes (Das zweite Buch der Könige, 81), the reference in v. 6 to the produce of her land during the years of her absence implies-as does 4:42-44 - that the famine has been somewhat intermittent. 
back to life (v. 4). Astonishingly, she and her son present themselves before him just as Gehazi is speaking of her, so that he can see that the son is still alive (v. 5), and he acknowledges the power of the miracle by restoring her land to her. But he himself seems to be under the shadow of death. It is no accident that Gehazi is now part of his entourage; Gehazi, who was not only banished by Elisha for his ungodly greed, but afflicted with leprosy, with its connotations of death and exclusion from YHWH's presence. ${ }^{69}$ What a suitable companion he is for Jehoram by this stage! And how ironic that Jehoram should ask him to recount Elisha's 'mighty deeds', when these deeds have ultimately passed him by, and when Elisha's next actions in the narrative will lead to his own death.

\section{Later Developments}

In obvious ways, all of Elijah's and Elisha's ministries have been bound up with the themes of life and death. Curse and blessing, famine and rain, military defeat and victory, sickness and restoration to life: these run through every episode in this central section of Kings. It could not be otherwise once Ahab, at the prompting of Jezebel, brought Baal into YHWH's land. The question hanging in the air has been: life for whom and death for whom? By the beginning of ch. 8 it is clear that Jehoram is marked for death, and that duly follows in ch. 9. Does the Northern Kingdom still have a hope? The implications of ch. 8 are ominous: Elisha's followers, whose gains have in the end been so slight, fade from view. ${ }^{70}$ Worse, $8: 11-13$ sees Elisha weeping at the devastation Hazael will inflict on Israel. ${ }^{71}$ But the fate of the Northern Kingdom has still to play itself out, and there will be a number of surprising turns to the story. ${ }^{72}$

${ }^{69}$ We need not assume that he is now healed (contra Hobbs, 2 Kings, 101); the reverse is likely, in view of the terms of Elisha's curse (5:27).

$70 \mathrm{We}$ do not hear of the Shunamite again. There is only one further reference to Elisha's followers, in 9:1, where 'one of the sons of the prophets' is sent to anoint Jehu. After that, they too disappear.

${ }^{71}$ Note especially the reference to the death of women and their children in v. 12, which contrasts with the blessings enjoyed by the Shunamite.

${ }^{72}$ Not least the fact that Jehu's coup (end of Ahab, end of Baal) does not also mark end of Aramean threat: see 10:32-33. Jehu's coup and elimination of Baal worship (chs. 9-10) certainly looks like the 'conquest of 


\section{Conclusions}

This article has argued that 2 Kings 2-8 uses literary techniques similar to those which (according to a by now well-established school of thought) occur elsewhere in Old Testament narrative: 'implicit commentary' (the analogical patterning of narratives, the use of type scenes); 'simple' juxtaposition, whereby the reader is invited to look for connections between the seemingly unconnected; the deliberate presentation of events out of chronological sequence. On this basis, and using the 'key' supplied by ch. 2, with its conquest echoes and its clear distinction between faithful and unfaithful Israel, it is possible to account for the present form of chs. 2-8. There is no need to postulate a complicated literary history, no need to re-arrange incidents to produce a more coherent sequence.

Not that all these techniques are used in the same way as elsewhere in the Old Testament. Thus, as regards narrative analogy, though I think there are reasonably clear links between the two incidents where Jehoram rips his garments (5:6-7; 6:30-31), or the two incidents where YHWH's horses and chariots feature $(6: 17 ; 7: 6$; in each case the point concerns the great contrast between the situations thus linked), other cases in 2 Kings 2-8 are less obvious: the suggestion that the accounts of the campaign against Moab (ch. 3) and the miraculous jar of oil (4:1-7) are both narratives of 'blessing coming to an end'; so, too, the view that the three narratives in 5:1-6:23 are all narratives of 'axe-heads restored'. I do not think that the analogies in these latter cases are illusory. Rather, following the interpretation of chs. 3-6 set out above, this is an unusual use of narrative analogy, to hint at an ultimately unrealised possibility. The looseness of the narrative links (which makes the reader correspondingly tentative in drawing analogies) is appropriate to a stage in 2 Kings where the paths of the nation Israel and Elisha's followers might still converge. The type-

the land' promised by ch. 2. Having initiated it, however, Elisha in effect dissociates himself from it: he sends one of the 'sons of the prophets' to anoint Jehu rather than going himself, and even tells this man to flee once he has anointed him (9:3). Even after the coup Israel remains enslaved to Jeroboam's idols (10:28-31). 
scene of 4:8-37 raises the same possibility, and in a similarly loose way (we are not sure in what sense, if at all, the son represents Israel at large). The episode in which the possibility is finally set aside (8:1-6) is one of the most striking examples in the Old Testament of the delayed revelation of a significant fact setting events preceding in a new light.

In 2 Kings 2-8 the narrator presents us with a puzzling, disjointed-seeming set of events and invites us to make sense of them. Having been drawn into the interpretative process, having with effort seen a pattern in these events, we feel, more forcefully than might have been the case with more direct narrative techniques, the certainty with which YHWH's judgment has worked itself out against Ahab's line. But not just that: there are few sadder parts of the Old Testament than these chapters in 2 Kings, where the narrator raises the possibility of Israel's return to YHWH, holds the possibility open for a number of chapters, and then finally shows how the possibility came to nothing, causing us to reflect on what has been lost. Judgment in these chapters may be sure, but it is anything but simple and painless. 